\author{
Markova T. \\ Ph. D., Associate Professor \\ Department of Accounting and Auditing \\ E-mail: markova.tetiana17@gmail.com \\ ORCID ID: 0000-0002-9437-2635 \\ Pchelianska G. \\ Assistant \\ Department of Accounting and Auditing \\ E-mail: gaya@te.net.ua \\ ORCID ID: 0000-0003-0944-986X
}

\author{
Vaskovska K. \\ Ph.D., Associate Professor \\ Department of Accounting and Auditing \\ E-mail: v.caterin17@gmail.com \\ ORCID ID: 0000-0001-8093-170X \\ Volodina 0. \\ Assistant \\ Department of Foreign Languages \\ Odessa National Academy of Food Technologies \\ Kanatna str., 112, Odesa, Ukraine, 65039 \\ E-mail: completeness7@mail.ru
}

\title{
INFORMATION SYSTEMS AND TECHNOLOGIES IN THE PROCESS OF EVALUATION ACTIVITIES
}

The article examines the essence of the concept of «evaluation activity» and approaches to its definition. The study shows the six main types of evaluation methodologies: methodology without calculations, target methodology of formation, methodology of the final approach, target methodology of formation, final methodology based on the criteria and methodology of formation on the basis of the criteria. The three main components of the system cycle to the organization of information support by automated information management systems of evaluation activity have been formulated and substantiated. The advantages and disadvantages of information systems and technologies used in the process of evaluation, accounting, analytical and control in order to generate economic information have been analyzed. The problem issues were investigated and the necessity of application of information systems at the stage of transactional processes was substantiated. The statistical dynamics of the number of enterprises using computers and the share of the average number of employees (including full-time and supplementary staff members), who used the computer, in \% to the average number of employees of the enterprise, was analyzed.

Key words: information systems and technologies, software, evaluation activity.

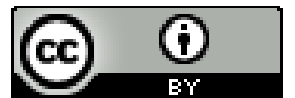

This work is licensed under a Creative Commons Attribution 4.0 International License http://creativecommons.org/licenses/by/4.0/
Statement of the problem and its connection with important scientific and practical tasks. For planning of economic projects, risks of the accepted financial and economic decisions, as well as for summarizing the results of completed stages of the activity on the management of objects of property, their assessment is important. To date, in the terms of sales and purchases relations, the assessment occupies an important place, in particular, if the owner acts as a participant in any deal with his property (business). For example, evaluation is crucial for a potential buyer or seller - when determining a reasonable price for an agreement (purchase and sale, exchange or other alienation); for creditors - when making a loan decision; for landlords - when installing a rent, tied to the market value of the object of lease; for investors when determining the base and future cost of a business development project; as well as for the owners of land plots; insurance companies; state and society as a whole [1]. Immediately, as practice shows, there is almost a misunderstanding between transaction process participants. And, therefore, the resolution of this kind of conflicts of the participants $\square$ interests can be done by an independent appraiser, who must professionally determine the value of the object of evaluation, reasonably persuade the subjects of the joint action that the calculated result of it is the objective monetary expression, which reflects the value of the object in the market at a given time and place. In this case, we can not do without the use and implementation of advanced innovative information technologies and software for calculations of financial and economic nature. Thus, a set of tools and methods that are part of information systems and technologies allow the user to search, collect, analyze, store, transmit and process the selected data. It should be noted that the number of movable and immovable property is increasing day by day: the number of apartments, residential and multi-apartment buildings, non-residential premises, office and shopping centers, vehicles, equipment and furniture, appliances and gadgets increases. With the increase in the material wealth of mankind, the need for the profession of «appraiser of property» appeared, because he can determine the market value of the property by the desired date. Recently, the organization and holding of round tables are increasingly observed, as well as the participants' interest in discussing and resolving issues [2]:

- legislative regulation of evaluation activities; trends in the development of normative-monetary 
evaluation of land, real estate, enterprises, businesses and their independent evaluation in Ukraine;

- estimation of the value of shares of enterprises at the present stage of development of forensic examinations;

- determining the material damage caused to the owner of the property;

- general estimation methods of the cost approach in determining the approximate cost of construction of complex objects, etc.

All this significantly increases the relevance of the study of organizational, methodological and practical support for the evaluation of property, the role of information technology and information systems in the process of development and regulation of evaluation activities in Ukraine.

The analysis of the latest publications on the problem. A number of scientists are engaged in the research of the actual questions concerning the evaluation activity: V.R. Kucherenko, Ya.P. Kvach, N.V. Smentyna, V.O. Ulibina [1], O.P. Ugrovetsky, A.P. Denisenko, T.P. Yegorova, A.O. Selivanov, S.G. Stetsenko [2], O.I. Pushkar, O.V. Vil'khivska [3], L.P. Dovgan, A.V. Surzhenko [4] and others whose achievements are very important for their practical application. The questions of use, implementation of information software for accounting, evaluation, control were dealt with by many scientists: S.V. Ivakhnenkov [5,6], N.V. Oljadichuk [7], O.P. Titova [8], A.P. Sirotinskaya, I.D. Lazarishina [9] and others. However, today there are topical issues regarding the nature of the information system and software for evaluation activities. The urgency of dealing with this problem is conditioned by the fact that the evaluation activity requires precise, true financial and economic calculations of business objects, envisages the development of forecast programs, the identification of strategic priorities of entrepreneurial activity, taking into account new challenges and strengthening of international requirements for the regulatory mechanisms of the Ukrainian economy.

Forming of the aims of the research. The highlighted problems identified the purpose of the study - a comprehensive analysis and description of the role of information technologies in the development of evaluation activities, and led to the following specific tasks:

- to define the main theoretical and methodological approaches to the analysis of the influence of information systems on the development of evaluation activities;

- to determine the specificity of the relationship between the development of evaluation activities and information technologies in Ukraine;

- to argue the need and features of modern information systems and technologies taking into account the requirements of the market environment.

Giving an account of the main results and their substantiation. The scientific and technological progress, on which economic development depends, every year more and more deeply penetrates not only in the life of the social sphere, but also in all spheres of entrepreneurial economy and evaluation activities that determine the competitiveness of any kind of activity [10].
According to V.F. Yatsenko, the end of the 20th and the beginning of the 21 st century have become a period of significant and rapid changes in the external environment of business: competition in many industries has gained a truly global character, the pace of the introduction of innovative technologies into production is increasing at an accelerated pace, the standards of quality of products and services become stricter, the possibilities of information systems and technologies are expanding rapidly, including world-wide networks, the control of the influence of enterprises on the state of the environment, by the society the surplus and excessive price of traditional energy resources is increasing. The management of many enterprises understands that, in addition to functional views on processes, they need new elements that will allow them to respond to external challenges and maintain business livelihoods [11].

It should be noted that the organization of automation of processes of using information systems and technologies is currently one of the tasks of enterprises to optimize the accounting, analytical and managerial process. The technogenic branch is developing very actively now and computer technologies and software occupy an important place in human and society activities. One of the main factors determining the effectiveness of information systems, according to A.P. Sirotinskaya, I.D. Lazarishina, [9] is the possibility of obtaining a more reliable result with less time and labor. In order to choose the best technology, or to evaluate and select the best applications that will be used to process information, you need to have specific identifiable indicators. It is on their basis that one can make choices and evaluate the efficiency and quality of the technology. It should be noted that authenticity, complexity and speed are among the criteria in the evaluation process.

The notion of evaluative activity has recently been discussed and is regarded as a kind of professional activity. Although, we know different approaches to defining the concept of «evaluation»:

- evaluation as a method of accounting;

- evaluation as a summary of the knowledge of the educational process.

The authors of Si Chen, Nor Mardziah Osman, Miguel Baptista Nunes, Guo Chao Peng [12] consider the process of evaluating information systems, which may differ in the nature of the process, that is, the evaluation can be modelling or final. This distinction is the result of the difference in carrying out the evaluation in connection with the cycle of design and development of information systems: it is formed during the design and development process; summing up is fulfilled at the end of this process. However, each of these types of evaluation may, in its turn, use different strategies, notably non-goalbased, goal-based and criterial evaluation depending on assessment motivation. Therefore, it leads to six main types of evaluation methodologies: a methodology without results, a methodology of the final approach, a target methodology of formation, non-target methodology of formation, a summary methodology based on motivation and a methodology of formation based on criteria without motivation. 
Professional appraisal activity, in accordance with the Law of Ukraine «On evaluation of property, property rights and professional appraisal activity in Ukraine», [13] is the activity of appraisers and subjects of evaluation activity, which consists in organizational, methodological and practical maintenance of property evaluation, consideration and preparation of conclusions regarding the value of the property. And, the subjects - are referred to these who are registered in accordance with the procedure of legislation individuals - entrepreneurs, as well as legal entities, regardless of their organizational and legal form and ownership, who carry out economic activities, which includes at least one appraiser, and who received the certificate of the subject of evaluation activity in accordance with the Law [13].

Professor at the University of Princeton, Carl Zeininger, says that time is the main source of competitive advantage, since it is «the only non-renewable resource, neither can it be bought nor reversed» [5]. Therefore, the use of the results of scientific and technological progress regarding the operational receipt of financial and operational information for decision-making in the field of entrepreneurial, evaluation activities is of considerable importance.

It should be noted that the process of evaluating with the help of information systems and technologies, in our opinion, includes three components that cover the important parts of the process of acceptance of the final result.

1. Information provision is a stage-base that provides the necessary input paper and electronic information (legal framework, regulations, standards, conceptual and theoretical principles and methods, primary accounting documents, statistical and financial reporting, contracts with buyers and suppliers, etc.) and communication support (telephone and skype - internet provision, etc.).

2. Processing of information-digital data - this is the stage of systematization, classification and implementation of economic calculations, their analysis and comparison using software application by an, electronic computer. This stage is characterized by the efficiency of the implementation of analytical algorithmic computational operations.

3. The adoption of well-grounded managerial decisions is the final stage in choosing the best option for evaluating a strategic project (property, business, etc.).

Thus, the way from obtaining information (accounting-analytical, financial-economic, social, environmental, normative-legislative, etc.) to the adoption of well-grounded managerial decisions is an interconnected system process, the so-called system cycle, which is reflected in Fig. 1.

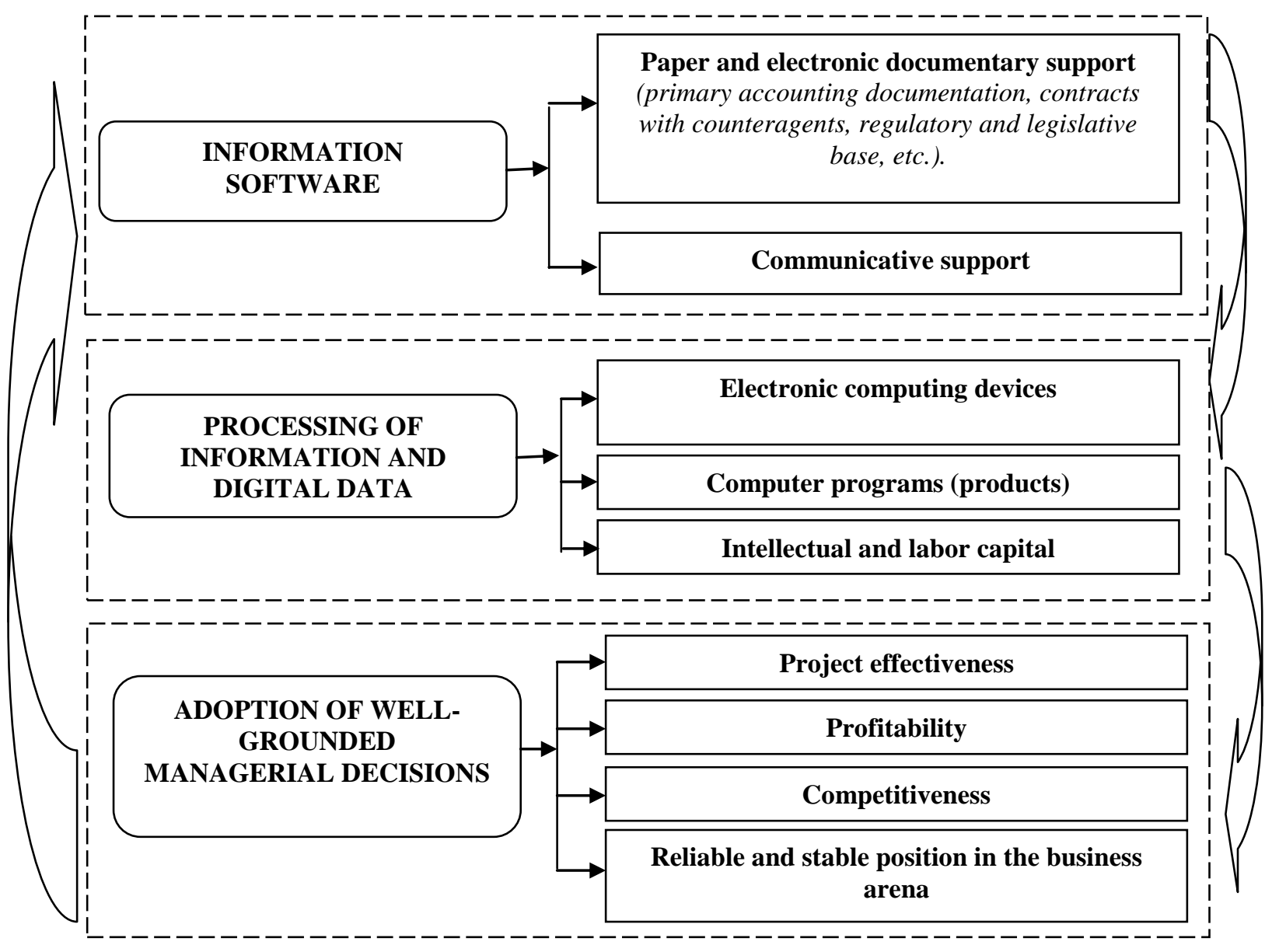

Fig. 1. System cycle to the organization of information support with automated information management systems *

*author's development 
In case of software applications, we note that this is the result of intellectual work [14], which is accounted for and can be used in the financial and business activities of the enterprise as intangible assets. According to $\mathrm{P}$ (C) $\mathrm{BO}$ No. 8, intangible assets are also software products, computer programs and databases, rights for know-how, as well as rights acquired through the purchase of licenses from patent holders [15]. In the market conditions of management, in the market of software products a wide range of programs for automation of accounting, financial and economic calculations has been presented.

Dovgan L.P. and Surzhenko A.V. believe that value-oriented management, being a synthesis of several business concepts, is reflected in various areas of the enterprise activity. Thus, the financial management, constructed in accordance with the principles of cost management, aims to formulate the shareholder value and explains the need for discounting of cash flows; strategic planning is based on the definition of the value creation as a result of investing in the relevant market segment and the formation of the competitive potential; accounting is unified according to its purpose in the context of this concept, creating information and analytical support for business evaluation processes. At the same time, the revolutionary in organizational behavior is the recognition of the leading idea of business creation that is valuable and rewarded to all stakeholders [4].

An important issue when conducting the pre-

vious procedures of the financial diagnosis is the choice of sources of information. It is here that potential buyers have a much smaller selection of different sources than property sellers, so estimating the value of the property will be based on the basis of a limited range of information resources, in particular financial and statistical reporting of the enterprise, own market research [4].

Modern information systems and technologies are not slowly being implemented, but are part of the life of all sectors of the society and all sectors of the country's economy. Over the past decade, the information technologies have increasingly penetrated into the business: automated design and financial, tax and management accounting systems, including the introduction of bar codes and production planning systems. To date, you will not find an enterprise that would not use modern technology at least for accounting. It is impossible to imagine the activities of a business entity without a current account in the bank, without the «client-bank» program, without the electronic mail, a computer system and a package of book-keeping accounting programs, national security services - without supercomputers, and the population without a laptop, pocket computers and smartphones [10]. Therefore, the question of using modern information systems and technologies, their advantages and disadvantages remain relevant both in the studies of methods for improving and efficiency working conditions in the enterprise and in the field of evaluation activities (Table 1).

Table 1

Advantages and disadvantages of using information systems and technologies in the evaluation process *

\begin{tabular}{|c|c|}
\hline Advantages & Disadvantages \\
\hline $\begin{array}{l}\text { Automation of information exchange through various types of communi- } \\
\text { cations }\end{array}$ & Dependence on the World Wide Web \\
\hline $\begin{array}{l}\text { Automation of evaluation activity on the basis of computer systems of } \\
\text { integrated information systems that assist in decision-making }\end{array}$ & \multirow{2}{*}{$\begin{array}{l}\text { The constant need to adapt to the mod- } \\
\text { ern requirements of time }\end{array}$} \\
\hline $\begin{array}{l}\text { Operational access to arbitrary accumulated information in order to effec- } \\
\text { tively use it for solving the set tasks in the future. }\end{array}$ & \\
\hline
\end{tabular}

* compiled by authors

Also, the disadvantages can be attributed to the high level of cybercrime, especially the deliberate breakdown of a well-established algorithmic calculated supplement of the system support for operational and settlement operations, which leads to false economic results. But this does not stop legal and physical persons from using computers. Thus, according to the statistics of the State Statistics Service of Ukraine, it has been determined that over the past seven years there has been a tendency towards an increase in the share of the average number of employees (including full-time and extrabudgetary staff members) who used computers in $\%$ to the average number of employees at the enterprise by $6,7 \%$ (Fig. 3), tak- ing into account the decrease of computer units at the enterprise by $20,7 \%$ (Fig. 2) (the decrease is possible due to the reduction of the number of enterprises in Ukraine as a whole).

Thus, the operational coverage of the public space and all spheres of the economy by information systems and technologies has recently been observed. It should be noted that measures for providing information on reproductive systems at the national, regional, commercial levels, stimulated the filling of socio-economic transformations and innovation development in the country. 


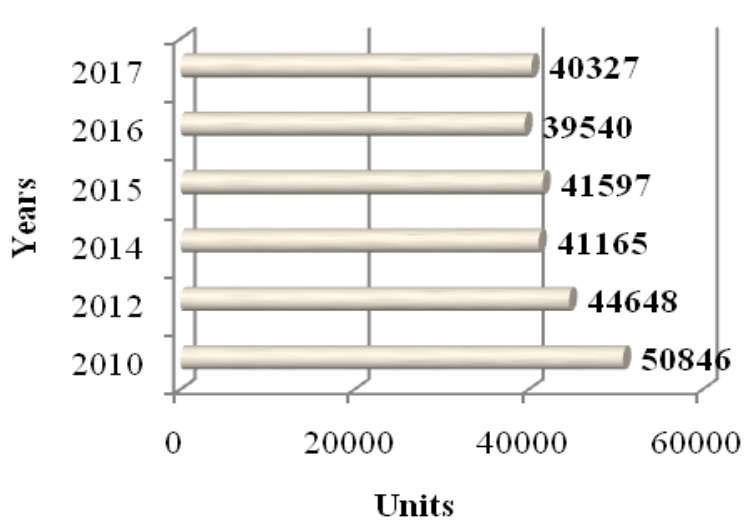

Fig. 2. Number of enterprises that used computers*$$
*
$$

* written by the authors according to the State Stat
Conclusions and prospects of the further in vestigations. The conducted studies have shown that information technologies today play an extremely important role in providing information interaction between people, as well as in accounting, analytical, managerial and evaluation activities. In addition to already existing traditional means of communication (telephone, telegraph, radio and television), in the social and economic sphere, electronic telecommunication systems, cloud technologies, e-mail, social information networks, facsimile transmission of information and other types of communication are increasingly used. These means are quickly assimilated by the culture of the modern society, since they not only create great conveniences, but also solve many industrial, social, economic and domestic problems.

The study of approaches to the definition of the essence and the concept of «evaluation» indicates many categories of its characteristics: the nature of the process (formulating or final), the nature of the strategy (without goals, assessment based on goals), according to the criteria; dependence on motivation. Therefore, it leads to six main types of evaluation methodologies: a methodology without results, a methodology of the final approach, a target methodology of formation, non-target methodology

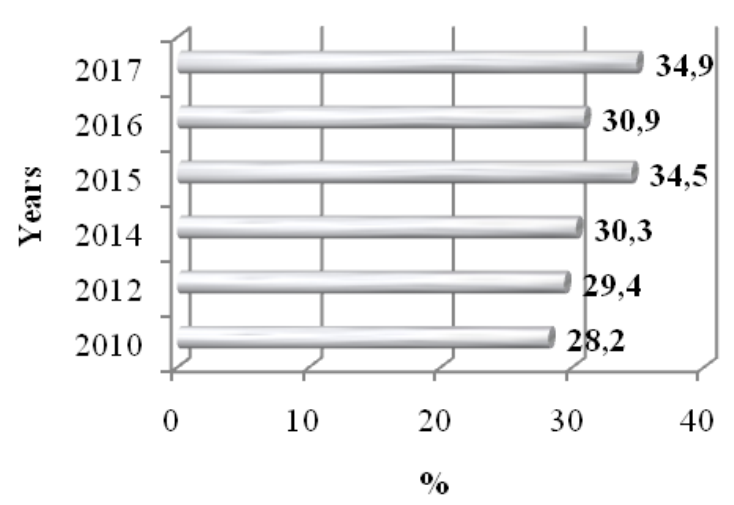

Fig. 3. Share of the average number of employees (icluding full-time and extrabudgetary staff members) who used the computer in \% of the average number of employees of the company* cs Service of Ukraine [16-21]

of formation, a summary methodology based on motivation and a methodology of formation based on the criteria without motivation.

Systematization and substantiation of the components of the organization of information support by automated information systems and technologies of management of valuation activities allowed to distinguish three parts that cover the important parts of the process of making the optimal decision regarding the value of the object. The advantages and disadvantages of information systems and technologies in the process of evaluation, accounting and control in order to generate economic information have been analyzed, indicating that they are widely used in the economic activity. The analyzed statistical dynamics of the number of enterprises that used computers showed a reduction by $20,7 \%$ and an increase by $6,7 \%$ of the average number of employees (including full-time and supplementary staff members) who used computers in $\%$ to the average number of employees of the enterprise. The problematic issues were investigated and the necessity of application of information systems at the stage of transactional processes was substantiated. It is precisely which software products are used to provide operational economic calculations remains the subject of the future research.

\section{References}

1. Kucherenko, V. R. (2009). Otsinka biznesu ta nerukhomosti. Kyiv: Tsentr uchbovoi literatury.

2. Petrova, I. A. (2018). Udoskonalennia pravovoho rehuliuvannia otsinky maina i mainovykh prav. Otsinka zemli. Profesiina ekspertyza i otsinochna diialnist. Publichne pravo (2nd ed., pp. 263-272).

3. Pushkar, O. I., \& Vilkhivska, O. V. (2016). Otsinka vartosti rozrobky tekhnolohii elektronnoho biznesu na pidpryiemstvi. Biznes Inform, (12), 88-94.

4. Dovhan, L. P., \& Surzhenko, A. V. (2017). Otsinka vartosti biznesu v umovakh vprovadzhennia vartisnooriientovanoho upravlinnia finansamy pidpryiemstv. Ekonomichnyi Visnyk Universytetu,(33 (1)), 293-302.

5. Ivakhnenkov, S. V. (2010). Naukove obgruntuvannia vprovadzhennia informatsiinykh tekhnolohii v audyti ta vnutrishnohospodarskomu kontroli. Ekonomichni Nauky, (7 (1)), oblik i finansy, 530-538.

97.

6. Ivakhnenkov, S. V. (2010). Kontrol finansovoi informatsii: Suchasni tekhnolohii. Finansy Ukrainy,(1), 87- 
7. Oliadnichuk, N. V. (2016). Informatsiini systemy v bukhhalterskomu obliku. Zbirnyk Naukovykh Prats Umanskoho Natsionalnoho Universytetu Sadivnytstva, (88 (2)), 198-206.

8. Titova, O. P. (2012). Osoblyvosti ta perevahy vykorystannia novitnikh informatsiinykh tekhnolohii v upravlinni ahrokholdynhu «Ukrlendfarminh». Visnyk Zhytomyrskoho Natsionalnoho Ahroekolohichnoho Universytetu, (2 (2)), 90-96.

9. Syrotynska, A. P., \& Lazaryshyna, I. D. (2008). Informatsiini systemy pidpryiemstva maloho biznesu. Kyiv: Tsentr uchbovoi literatury.

10. Markova, T. D. (2016). Systemnyi pidkhid do orhanizatsii oblikovo-analitychnoho zabezpechennia avtomatyzovanymy informatsiinymy systemamy upravlinnia pidpryiemstvom. In V. V. Nemchenko (Ed.), Naukovometodychni aspekty oblikovo-analitychnoi systemy pidpryiemstva (pp. 256-266). Odesa: Feniks.

11. Yatsenko, V. F. (2013). Teoretyko-metodolohichnyi henezys sutnosti ta zmistu oblikovo-analitychnoho zabezpechennia upravlinnia pidpryiemstvom. Visnyk ZhDTU, (3 (65)), 75-82.

12. Chen, S., Osman, M., Nunes, J. M. B., \& Peng, G. C. (2011). Information systems evaluation methodologies. In Proceedings of the IADIS International Workshop on Information Systems Research Trends, Approaches and Methodologies (ISRTAM). Retrieved January 08, 2019, from http://eprints.whiterose.ac.uk/74740/1/WRRO_74740.pdf

13. Pro otsinku maina, mainovykh prav ta profesiinu otsinochnu diialnist v Ukraini: Zakon Ukrainy vid 12 lypnia 2001 roku №2658-III za stanom na 26.11.2015r. (2015). Retrieved January 9, 2019, from https://search.ligazakon.ua/1_doc2.nsf/link1/T012658.html

14. Shypunova, O. V. (2008). Ob'iekty intelektualnoi vlasnosti informatsiinykh system. Sotsialno-ekonomichni Problemy Suchasnoho Periodu Ukrainy. Finansovyi Rynok Ukrainy: Hlobalizatsiia Ta Yevro Intehratsiia (Zbirnyk Naukovykh Prats), (1 (69)), 454-460.

15. Nematerialni aktyvy: Polozhennia (standart) bukhhalterskoho obliku 8: Zatv. nakazom Minfinu vid 18 zhovtnia 1999 roku № 242 za stanom na 09.08.2013r. (2013). Retrieved January 10, 2019, from http://search.ligazakon.ua/1_doc2.nsf/link1/REG4043.html

16. Vykorystannia informatsiino-komunikatsiinykh tekhnolohii na pidpryiemstvakh za 2017 rik. (2019). Retrieved January 10, 2019, from http://ukrstat.gov.ua

17.Vykorystannia informatsiino-komunikatsiinykh tekhnolohii na pidpryiemstvakh Ukrainy. (2017). Statystychnyi Biuleten Derzhavnoi Sluzhby Statystyky Ukrainy, 1-30.

18.Vykorystannia informatsiino-komunikatsiinykh tekhnolohii na pidpryiemstvakh Ukrainy. (2016). Statystychnyi Biuleten Derzhavnoi Sluzhby Statystyky Ukrainy, 1-24.

19.Vykorystannia informatsiino-komunikatsiinykh tekhnolohii na pidpryiemstvakh Ukrainy.

(2015). Statystychnyi Biuleten Derzhavnoi Sluzhby Statystyky Ukrainy, 1-28.

20.Vykorystannia informatsiino-komunikatsiinykh tekhnolohii na pidpryiemstvakh Ukrainy.

(2013). Statystychnyi Biuleten Derzhavnoi Sluzhby Statystyky Ukrainy, 1-44.

21.Vykorystannia informatsiino-komunikatsiinykh tekhnolohii na pidpryiemstvakh Ukrainy.

(2011). Statystychnyi Biuleten Derzhavnoi Sluzhby Statystyky Ukrainy, 1-43.

Received 6 February 2019

Approved 20 February 2019 Available in Internet 19.03.2019

\section{Маркова Т.Д. \\ кандидат экономических наук, старший преподаватель кафедра учета и аудита \\ E-mail: markova.tetiana17@gmail.com ORCID ID: 0000-0002-9437-2635}

Пчелянская Г.Б. старший преподаватель кафедра учета и аудита E-mail: gaya@te.net.ua ORCID ID: 0000-0003-0944-986X
Васьковская Е.А.

кандидат экономических наук, старший преподаватель кафедра учета и аудита

E-mail: v.caterin17@gmail.com

ORCID ID: 0000-0001-8093-170X

\section{Володина Е.П.}

ассистент

кафедра иностранных языков

Одесская национальная академия пищевых технологий ул. Канатная, 112, г. Одесса, Украина, 65039

E-mail: completeness7@mail.ru

\section{ИНФОРМАЦИОННЫЕ СИСТЕМЫ И ТЕХНОЛОГИИ В ПРОЦЕССЕ ОЦЕНОЧНОЙ ДЕЯТЕЛЬНОСТИ}

В статье рассматривается сущность понятия «оценочная деятельность» и подходы к ее определению. Исследование показало наличие многих категорий, которые ее характеризуют, а именно, с нашей точки зрения, о шести основных типах методологий оценки: методология без итогов, методология итогового подхода, целевая методология формирования, безцелевая методология фрормирования, итоговая методология на основе мотивации и методологию формирования на основе критериев без мотивации. 
Проведенные исследования специфики взаимосвязи между развитием оценочной деятельности и информационными технологиями в Украине свидетельствуют, что информационные технологии сегодня играют исключительно важную роль в обеспечении информационного взаимодействия между людьми, а также в системах учетно-аналитической, управленческой и оценочной деятельности. Эти средства быстро ассимилируются культурой современного общества, так как они не только создают большие удобства, но и решают многие производственные, социальные, экономические и бытовые проблемы.

Систематизация и обоснование составляющих системы организации информационного обеспечения автоматизированными информационными системами и технологиями управления оценочной деятельности позволило выделить три части (информационное обеспечение; обработка информационно-цифровых данных, принятие обоснованных управленческих решений), которые охватывают важные участки процесса принятия оптимального решения по стоимостной оценки объекта.

Проанализированы преимущества и недостатки информационных систем и технологий в процессе оценки, учета и контроля с целью фрормирования экономической информации свидетельствует о широком их использования в хозяйственной деятельности. Проанализирована статистическая динамика количества предприятий, которые использовали компьютеры, что показало их сокращение на $20,7 \%$ и увеличение на 6,7\% доли среднего количества работников (включая штатных и внештатных), которые использовали компьютер, в \% к средней численности работников предприятия. Исследованs проблемные вопросы и обоснована необходимость применения информационных систем на этапе трансакционных процессов.

Ключові слова: інформаційні системи і технології, програмне забезпечення, оціночна діяльність.

\section{Маркова Т.Д.}

кандидат економічних наук, старший викладач кафедра обліку та аудиту

E-mail: markova.tetiana17@gmail.com

ORCID ID: 0000-0002-9437-2635

Пчелянська Г.Б.

старший викладач кафедра обліку та аудиту

E-mail: gaya@te.net.ua

ORCID ID: 0000-0003-0944-986X
Васьковська К.О.

кандидат економічних наук, старший викладач кафедра обліку та аудиту

E-mail: v.caterin17@gmail.com

ORCID ID: 0000-0001-8093-170X

Володіна О.П.

асистент

кафедра іноземних мов

Одеська національна академія харчових технологій вул. Канатна, 112, м. Одеса, Україна, 65039

E-mail: completeness7@mail.ru

\section{ІНФОРМАЦІЙНІ СИСТЕМИ І ТЕХНОЛОГІЇ В ПРОЦЕСІ ОЦІНОчнОї дІяЛЬНОСТІ}

У статті розглядається сутність поняття «оціночна діяльність» та підходи до її визначення. Дослідження свідчить про багато категорій її характеристики, а саме, з нашої точки зору, про шести основних типів методологій оцінювання: методологія без підсумків, методологія підсумкового підходу, цільова методологія формування, без цільова методологія формування, підсумкова методологія на основі мотивації та методологію формування на основі критеріїв без мотивації.

Проведені дослідження специфіки взаємозв'язку між розвитком оціночної діяльності та інформаційними технологіями в Україні свідчать, що інформаційні технології сьогодні відіграють винятково важливу роль у забезпеченні інформаційної взаємодії між людьми, а також в системах обліковоаналітичної, управлінської та оціночної діяльності. Ці засоби швидко асимілюються культурою сучасного суспільства, так як вони не тільки створюють великі зручності, але і вирішують багато виробничі, соціальні, економічні і побутові проблеми.

Систематизація та обґрунтування складових системи організації інформаційного забезпечення автоматизованими інформаційними системами і технологіями управління оціночної діяльності дозволило виділити три частини (інформаційне забезпечення; обробка інформаційно-цифрових даних; прийняття обґрунтованих управлінських рішень), які охоплюють важливі ділянки процесу прийняття оптимального рішення щодо вартісної оцінки об'єкту.

Проаналізовані переваги і недоліки інформаційних систем і технологій в процесі оцінки, обліку та контролю з метою формування економічної інформації свідчить про широке їх використання в господарській діяльності. Проаналізована статистична динаміка кількості підприємств, які використовували комп'ютери показало їх скорочення на 20,7\% та збільшення на 6,7\% частки середньої кількості працівників (включаючи штатних та позаштатних), які використовували комп'ютер, у \% до середньої кількості працівників підприємства. Досліджено проблемні питання та обґрунтовано необхідність застосування інформаційних систем на етапі трансакційних процесів.

Ключові слова: інформаційні системи і технології, програмне забезпечення, оціночна діяльність. 


\section{Література}

1. Оцінка бізнесу та нерухомості: навч.пос. / Кучеренко В.Р. та ін. К.: Центр учбової літератури, 2009. $200 \mathrm{c}$.

2. Петрова I.А. Засідання круглого столу за темою: «Удосконалення правового регулювання оцінки майна і майнових прав. Оцінка землі. Професійна експертиза і оціночна діяльність» // Публічне право. 2018. № 2. C. 263-272.

3. Пушкар О.І., Вільхівська О.В. Оцінка вартості розробки технологій електронного бізнесу на підприємстві // Бізнес Інформ. 2016. № 12. С. 88-94.

4. Довгань Л.П., Сурженко А.В.Оцінка вартості бізнесу в умовах впровадження вартісноорієнтованого управління фінансами підприємств // Економічний вісник університету. 2017. Вип. 33(1). С. 293302.

5. Івахненков С.В. Наукове обгрунтування впровадження інформаційних технологій в аудиті та внутрішньогосподарському контролі // Економічні науки. Серія. Облік і фінанси. 2010. Вип. 7(1). С. 530-538. C. $87-97$

6. Івахненков С.В. Контроль фінансової інформації: сучасні технології // Фінанси України. 2010. № 1.

7. Оляднічук Н.В. Інформаційні системи в бухгалтерському обліку // Збірник наукових праць Уманського національного університету садівництва. 2016. Вип. 88(2). С. 198-206.

8. Тітова О.П. Особливості та переваги використання новітніх інформаційних технологій в управлінні агрохолдингу «Укрлендфармінг» // Вісник Житомирського національного агроекологічного університету. 2012. № 2(2). С. 90-96.

9. Сиротинська А.П., Лазаришина І.Д. Інформаційні системи підприємства малого бізнесу: навч.пос. К.: Центр учбової літератури, 2008. 264 с.

10. Маркова Т.Д. Системний підхід до організації обліково-аналітичного забезпечення автоматизованими інформаційними системами управління підприємством // Науково-методичні аспекти обліковоаналітичної системи підприємства: монографія за заг.ред. д.е.н., проф. Немченко В.В. ОНАХТ. Одеса: Фенікс, 2016. 352 c. (C.256-266).

11. Яценко В.Ф. Теоретико-методологічний генезис сутності та змісту обліково-аналітичного забезпечення управління підприємством // Вісник ЖДТУ. 2013. № 3 (65). С. 75-82.

12. Chen, S., Osman, M., Nunes, J.M.B. and Peng, G.C. (2011). Information systems evaluation methodologies. In; Proceedings of the IADIS International Workshop on Information Systems Research Trends, Approaches and Methodologies (ISRTAM), 20 July 2011, Rome, Italy. URL: http://eprints.whiterose.ac.uk/74740/1/WRRO_74740.pdf (дата звернення: 08.01.2019)

13. Про оцінку майна, майнових прав та професійну оціночну діяльність в Україні: Закон України від 12 липня 2001 року №2658-III за станом на 26.11.2015p. Kиїв. URL: https://search.ligazakon.ua/1_doc2.nsf/link1/T012658.html (дата звернення: 09.01.2019).

14. Шипунова О.В. Об’єкти інтелектуальної власності інформаційних систем // Соціально-економічні проблеми сучасного періоду України. Фінансовий ринок України: глобалізація та євро інтеграція (Збірник наукових праць) / НАН України. Ін-т регіональних досліджень. Львів, 2008. Вип.1(69). С.454-460

15. Нематеріальні активи: Положення (стандарт) бухгалтерського обліку 8: затв. наказом Мінфіну від 18 жовтня 1999 року № 242 за станом на 09.08.2013p. - URL: http://search.ligazakon.ua/1_doc2.nsf/link1/REG4043.html (дата звернення: 10.01.2019).

16. Використання інформаційно-комунікаційних технологій на підприємствах за 2017 рік: [Веб-сайт]. Київ, 2019. URL: http://ukrstat.gov.ua (дата звернення: 10.01.2019).

17. Використання інформаційно-комунікаційних технологій на підприємствах України // Статистичний бюлетень Державної служби статистики України. Київ. 2017. С.30.

18. Використання інформаційно-комунікаційних технологій на підприємствах України // Статистичний бюлетень Державної служби статистики України. Київ. 2016. С.24.

19. Використання інформаційно-комунікаційних технологій на підприємствах України // Статистичний бюлетень Державної служби статистики України. Київ. 2015. С.28.

20. Використання інформаційно-комунікаційних технологій на підприємствах України // Статистичний бюлетень Державної служби статистики України. Київ. 2013. С.44.

21. Використання інформаційно-комунікаційних технологій на підприємствах України // Статистичний бюлетень Державної служби статистики України. Київ. 2011. С.43.

Стаття надійшла 6.02.2019

Стаття прийнята до друку 20.02.2019

Доступно в мережі Internet 19.03.2019

Цитування згідно ДСТУ 8302:2015

Markova T., Vaskovska K., Pchelianska G., Volodina O. Information systems and technologies in the process of evaluation activities // Food Industry Economics. 2019. Vol.11, Issue 1. P. 111-118; doi: 10.15673/fie.v11i1.1302

Cite as APA style citation

Markova T., Vaskovska K., Pchelianska G., \& Volodina O. (2019). Information systems and technologies in the process of evaluation activities. Food Industry Economics, 11(1), 111-118; doi: 10.15673/fie.v11i1.1302 